\title{
Geotrichum bryndzae sp. nov., a novel asexual arthroconidial yeast species related to the genus Galactomyces
}

\author{
Correspondence \\ Pavol Sulo \\ sulo@fns.uniba.sk
}

\author{
Pavol Sulo, ${ }^{1}$ Michal Laurenčík, ${ }^{1}$ Silvia Poláková, ${ }^{1,2}$ Gabriel Minárik ${ }^{3}$ \\ and Elena Sláviková 4
}

${ }^{1}$ Comenius University, Faculty of Natural Sciences, Department of Biochemistry, Mlynská Dolina, Bratislava 842 15, Slovakia
${ }^{2}$ Cell and Organism Biology, Lund University, Soelvegatan 35, Lund 22362, Sweden
${ }^{3}$ Comenius University, Faculty of Natural Sciences, Department of Molecular Biology, Mlynská Dolina, Bratislava 842 15, Slovakia
${ }^{4}$ Culture Collection of Yeasts, Institute of Chemistry, Slovak Academy of Sciences, Dúbravská cesta 9, Bratislava 842 38, Slovakia

\begin{abstract}
Ten strains of an asexual arthroconidial yeast species were isolated from Bryndza, a traditional Slovak artisanal sheep cheese, which was manufactured from raw milk during a 4-month summer production period at two Slovakian sites (the northern Ružomberok and the central-southern Tisovec areas). Sequence comparison of the D1/D2 domains of the large-subunit rRNA gene revealed that this yeast represents a novel species of the genus Geotrichum, which contains anamorphs of the ascogenous genus Galactomyces, for which the name Geotrichum bryndzae sp. nov. is proposed (type culture CCY $16-2-1^{\top}=N R R L Y-48450^{\top}=$ CBS $11176^{\top}$ ). The novel species is most closely related to Geotrichum silvicola NRRL Y $-27641^{\top}$, although yeasts with identical or very similar sequences have been found throughout the world.
\end{abstract}

The taxonomy of the arthroconidial ascomycetous genus Geotrichum Link: Fr. (Hemiascomycetes) is still being developed, although these yeast-like fungi have been studied quite extensively by conventional taxonomy as well as by DNA sequence comparisons (de Hoog et al., 1986; Smith et al., 2000; Naumova et al., 2001; Smith \& Poot, 2003; de Hoog \& Smith, 2004). Geotrichum represents the anamorphic state of species of the genera Dipodascus Lagerheim and Galactomyces Redhead \& Malloch (de Hoog et al., 1998a, b), as demonstrated by sequence divergence of the rRNA subunits (Kurtzman \& Robnett, 1998; Ueda-Nishimura \& Mikata, 2000). Until 1998, the genus Geotrichum contained 11 species, five of which have their teleomorph in the genus Dipodascus and two in the genus Galactomyces, while the remaining four species have no known sexual state (de Hoog et al., 1998a, b). Since 1998, several revisions have been suggested and novel species have been proposed (Naumova et al., 2001; de Hoog \& Smith, 2004). Less closely related Dipodascus

The GenBank/EMBL/DDBJ accession number for the large-subunit rRNA gene sequence of strain CCY 16-2-1 ${ }^{\top}$ is EU186073, and those of small-subunit rRNA gene sequences of strain CCY $16-2-1^{\top}$ are EU433455 and EU433456.

The Mycobank (http://www.mycobank.org) accession number for G. bryndzae sp. nov. is MB 512675. species from the so-called group 2 clade were renamed Magnusiomyces, with the anamorph for this genus being Saprochaete (de Hoog \& Smith, 2004).

Kurtzman \& Robnett (1998) determined that domains 1 and 2 (D1/D2) ( 600 nt) of the large-subunit rRNA gene are sufficiently variable to resolve individual biologically defined species. They also reported the sequences of all known ascomycetous yeasts, and Fell et al. (2000) published the D1/D2 sequences of known basidiomycetous yeasts. From these extensive data, Kurtzman \& Robnett (1998) deduced simple rules, which generally defined strains showing 6 or more non-contiguous substitutions $(1 \%)$ as likely to represent separate species (Kurtzman, 2006). Currently, the only exception to this prediction is among interfertile strains of Clavispora lusitaniae, which are unusually polymorphic in a $90 \mathrm{bp}$ region of the D2 domain (Lachance et al., 2003).

Recently, DNA sequence comparison has allowed the description of two novel species, Geotrichum silvicola (Pimenta et al., 2005) and Geotrichum vulgare (Wuczkowski et al., 2006).

During a survey of yeasts and fungi associated with Bryndza, a traditional Slovak artisanal sheep cheese, we isolated ten strains of asexual arthroconidial yeasts 
identified by conventional taxonomy as Galactomyces/ Geotrichum strains. These yeasts were found in all Bryndza samples collected from two dairies located in different geographical regions during the summer of 2003 (June-September). Sequence comparison of the D1/D2 domains of the large-subunit rRNA gene revealed that these isolates belong to the same novel Geotrichum species (Laurenčík et al., 2008), related to Geotrichum silvicola (Pimenta et al., 2005).

\section{Isolation and characterization of yeasts}

The strains described in this study were isolated from samples of Bryndza collected from two dairies, one located in Ružomberok, in the north of Slovakia $\left(49^{\circ} 04^{\prime} 45^{\prime \prime} \mathrm{N} 19^{\circ}\right.$ $18^{\prime} 09^{\prime \prime} \mathrm{E}$; altitude $464 \mathrm{~m}$ ), and the other in Tisovec, in

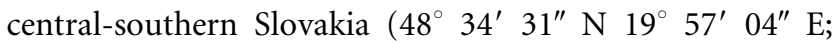
altitude $310 \mathrm{~m}$ ). Monthly samples were taken during JuneSeptember 2003, 14 days after clothing, and they were transported immediately to the laboratory, maintained at $4{ }^{\circ} \mathrm{C}$ and analysed in triplicate within $24 \mathrm{~h}$. Detailed isolation procedures were described by Laurenćík et al. (2008). Yeasts were characterized by standard methods (Yarrow, 1998) and identified using the keys of Kurtzman \& Fell (1998) and Barnett et al. (2000). Their ability to form asci was examined on sporulation media [Gorodkowa agar, 5\% malt extract agar, cornmeal agar, McClary's acetate agar and yeast sporulation medium $(0.1 \%$ yeast extract, $1 \%$ potassium acetate, $0.05 \%$ glucose and $2 \%$ agar)].

\section{DNA sequence analysis}

Cultivation, DNA extraction and PCR were carried out as described by Laurenćík et al. (2008). Briefly, the divergent D1/ D2 domain (nucleotides 63-642 for Saccharomyces cerevisiae) at the $5^{\prime}$ end of the rRNA gene of the cytoplasmic large ribosomal subunit was amplified by PCR with primers NL1 (5'-GCATATCAATAAGCGGAGGAAAAG) and NL4 (5'GGTCCGTGTTTCAAGACGG) as described by Kurtzman \& Robnett (1998). To obtain clear sequences, PCR products were cloned in the pCR-Blunt II-TOPO vector of the Zero Blunt TOPO PCR Cloning kit (Invitrogen) according to the manufacturer's instructions.

Mitochondrial DNA (mtDNA) was prepared by a modification of the original protocol described by Defontaine et al. (1991). Parts of the gene for the small rRNA subunit ( $r n s)$ were amplified by two sets of primers, SSU1 (5'GTGCCAGCAGTCGCGGTAATAC) plus SSU2 (5'-GGATTATCGAATTAAATAACATGCTCCACTG) and SSU3 (5' CAGTGGAGCATGTTAAATTCGATAATCC) plus SSU5 (5'-CAGGTTCCCCTACAGTAACTGTATTTCAACTT), in 36 PCR cycles of denaturation at $94{ }^{\circ} \mathrm{C}$ for $1 \mathrm{~min}$, annealing at $52{ }^{\circ} \mathrm{C}$ for $1 \mathrm{~min}$ and extension at $72{ }^{\circ} \mathrm{C}$ for 2 min.

Individual PCR products and those cloned in plasmids were purified with the Novagen SpinPrep Gel DNA kit or
Qiagen Plasmid Mini kit (Qiagen). Purified DNA was sequenced directly with one of the amplification primers (or sequencing primers $-21 \mathrm{M} 13 \mathrm{~F}$ or $-48 \mathrm{M} 13 \mathrm{R}$ ) using an Applied Biosystems BigDye Terminator v3.1 cycle sequencing kit and ABI3100-Avant Genetic Analyzer (Applied Biosystems). Sequences were edited in CHROMAs version 1.45 and compared with the NCBI database (http:// www.ncbi.nlm.nih.gov/) by the BLASTN program (Altschul et al., 1990, 1997).

The sequences were aligned with the CLUSTAL $\mathrm{W}$ multiple sequence alignment program included in the CLUSTAL_X 1.8 package (Thompson et al., 1997). Rooted phylogenetic trees were constructed with the neighbour-joining method of the CLUSTAL_X 1.8 package. The stability of individual branches was assessed by the bootstrap method (Felsenstein, 1988), and numbers given at nodes are scores with which a given internode appeared in 1000 bootstrap replicates.

The number of nuclei was examined by DAPI staining, according to the specific fluorescence pattern as previously described (Marinoni et al., 1999), using a fluorescent microscope equipped with a DAPI optical filter.

\section{Classification and ecology}

Typical characteristics for the members of Galactomyces/ Dipodascus/Geotrichum clade and also for the novel strains are the assimilation of D-glucose, D-galactose, L-sorbose, glycerol, DL-lactate, succinate and ethanol as carbon sources. Some differences were observed when the novel species was compared with Galactomyces geotrichum. The novel species does not use ribitol or D-mannitol. In order to separate the novel species from Geotrichum silvicola, its closest relative, assimilation of D-glucitol and D-glucosamine can be used; Geotrichum silvicola assimilates Dglucitol and does not assimilate D-glucosamine.

The anamorphic species of the genus Geotrichum can be distinguished from their teleomorphs in the genera Dipodascus and Galactomyces by their inability to form asci. However, typical asci were not found after cultivation on the most common yeast sporulation media. In contrast, Galactomyces geotrichum NRRL $\mathrm{Y}-17569^{\mathrm{T}}$ produced a number of spherical asci, each containing a single spore which can be seen on DAPI staining (not shown).

The large-subunit rRNA gene D1/D2 domain sequence was analysed for five of the ten novel isolates. Three strains provided identical sequences and the other two isolates had single and double nucleotide polymorphisms in different positions. The DNA polymorphism was confirmed by sequencing of PCR products cloned in pCR-Blunt IITOPO. Sequence comparison with the GenBank database revealed 12 nucleotide differences in a 545 bp sequence from Galactomyces geotrichum NRRL Y-17569 ${ }^{\mathrm{T}}$ and 16 substitutions in comparison with Galactomyces sp. NRRL Y-6418 (Kurtzman \& Robnett, 1998). Additionally, the DNA sequence exhibited variation in 18 nucleotides from 
the sequence of the type strain of the recently described species Geotrichum vulgare (Wuczkowski et al., 2006) and 6 substitutions in 542 nucleotides from the sequence of the type strain of Geotrichum silvicola (Pimenta et al., 2005).

When the rate of divergence and the inability to form asci are considered together, the isolate found in Bryndza is most likely an anamorphic form of a novel Geotrichum species.

Phylogenetic analysis of the Dipodascus clade (Kurtzman \& Robnett, 1998) involving the novel species supported this conclusion, especially when the high bootstrap values show clear separation on the phylogenetic tree for all the lineages (Fig. 1). The novel species belonged to a clade of several Galactomyces species. Kurtzman \& Robnett (1998) suggested that there is no basis for maintaining the separate genera Galactomyces and Dipodascus, as they are phylogenetically intertwined. However, Naumova et al. (2001) have disagreed because of the common mating type system and the high DNA-DNA reassociation.

A high degree of divergence was also shown by two sequences obtained from mitochondrial DNA ( $r n s$ gene), where 12 substitutions in the $504 \mathrm{bp}$ amplified segment and 12 substitutions in the second 350 bp PCR product were found when the sequences of strain CCY $16-2-1^{\mathrm{T}}$ (GenBank accession numbers EU429455 and EU429456) were aligned with those of Galactomyces geotrichum NRRL Y-17569 ${ }^{\mathrm{T}}$ (EU429453, EU429454).

Galactomyces/Geotrichum species are quite ubiquitous since they are involved in biodegradation and depollution. They are recognized as an integral part of the microbiota of some food products. In particular, Geotrichum candidum is naturally present in raw milk (Desmasures et al., 1997) and it has long been accepted to be an important component of the microbiota of soft cheeses such as Camembert and semi-fresh goat's and ewe's milk cheeses (reviewed by
Boutrou \& Guéguen, 2005). Yeasts with the same D1/D2 sequence as the novel strains identified in Bryndza cheese have been found in Asia among cow rumen microbiota (uncultured fungus clone FE24) and also in Chinese koji (daqu) (GenBank accession no. DQ912852; not shown in Fig. 1). Conspecific strains (with minor divergences in the sequence) are preserved in the Chinese Industry Culture Collection (GenBank accession no. DQ912846) and among microbes degrading fats and oils in Vietnam (DQ377646).

On the basis of the results presented here, a novel species of the genus Geotrichum is described to accommodate these strains from Bryndza cheese, Geotrichum bryndzae sp. nov.

\section{Latin diagnosis of Geotrichum bryndzae Sulo, Laurenčík, Poláková, Minárik et Sláviková sp. nov.}

Cultura in agaro malti post dies $7\left(25^{\circ} \mathrm{C}\right)$ plana, sicca, capillata et candida. Post dies 7 mycelium verum et arthroconidia formantur. In agaro Solanum tuberosum et glucosum post dies 7 mycelium verum et arthroconidia formantur. Asci nec ascosporae non formantur. Glucosum non fermentatur. D-Glucosum, D-galactosum, D-xylosum, Lsorbosum (lente), glucosaminum (lente), glycerolum, 2ketogluconatum (lente), acidum lacticum, acidum succinicum, acidum citricum (lente), ethanolum propan-1,2diolum, butan-2,3-diolum et assimilantur, at non D-ribosum, L-arabinosum, D-arabinosum, L-rhamnosum, maltosum, $\alpha, \alpha-$ trehalosum, cellobiosum, salicinum, arbutinum, melibiosum, sucrosum, lactosum, raffinosum, melezitosum, inulinum, amylum solubile, erythritolum, ribitolum, xylitolum, Larabinitolum, D-mannitolum, galactitolum, myo-inositolum, D-glucono-1,5-lactonum, 5-keto-D-gluconatum, D-gluconatum, D-glucuronatum, et methanolum. Ethylaminum et cadaverinum assimilantur et non natrium nitricum, natrium nitrosum et lysinum. Ad crescentiam vitaminae externae non necessariae sunt. Augmentum in $28{ }^{\circ} \mathrm{C}$, at non $42{ }^{\circ} \mathrm{C}$. Typus

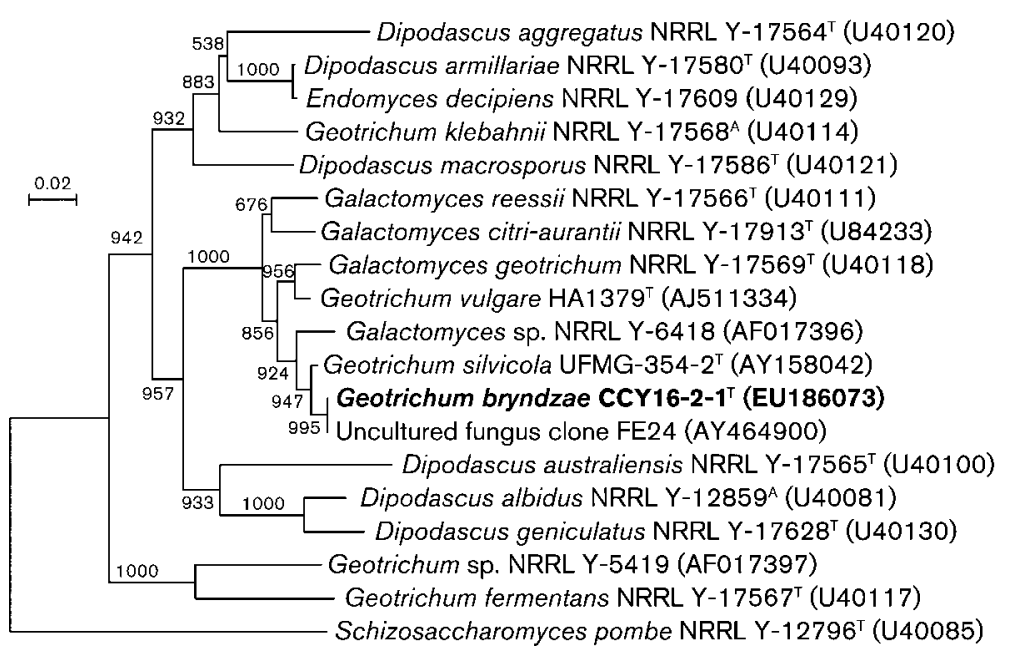

Fig. 1. Phylogenetic tree of the Dipodascus clade containing the novel species Geotrichum bryndzae. Neighbour-joining tree based on nucleotide sequences of the D1/D2 region in the $26 \mathrm{~S}$ rRNA gene of the novel Geotrichum species and its relatives from the Dipodascus clade (Kurtzman \& Robnett, 1998). The tree also includes the recently described species Geotrichum vulgare (Wuczkowski et al., 2006) and Geotrichum silvicola (Pimenta et al., 2005). Branch lengths are proportional to nucleotide differences and numbers at nodes are frequencies of a given branch appearing in 1000 bootstrap replications (frequencies under $50 \%$ not given). The outgroup in this analysis was Schizosaccharomyces pombe NRRL $\mathrm{Y}-12796^{\top}$. Bar, $2 \%$ sequence divergence. 
CCY $16-2-1^{\mathrm{T}}\left(=\right.$ NRRL Y $\left.-48450^{\mathrm{T}}=\mathrm{CBS} 11176^{\mathrm{T}}\right)$, collec tione zymotica Culture Collection of Yeasts in the Institute of Chemistry, Slovak Academy of Sciences.

\section{Description of Geotrichum bryndzae Sulo, Laurenčík, Poláková, Minárik and Sláviková sp. nov.}

Geotrichum bryndzae (brynd'zae. N.L. gen. n. bryndzae of Bryndza, a traditional Slovak artisanal raw sheep milk cheese, the source of isolation of the first strains).

After 7 days on malt extract-yeast extract agar at $25{ }^{\circ} \mathrm{C}$, colonies are white, flat, dry and powdery to finely hairy. Arthroconidia are abundantly present (Fig. 2). The hyphae are 3-7 $\mu \mathrm{m}$ wide with early disarticulation into cubic arthroconidia containing mostly three or four nuclei. Arthroconidia are 5.8-6.6 $\mu \mathrm{m}$ wide and 6.6-13.2 $\mu \mathrm{m}$ long. Abundant true mycelium and arthroconidia are formed on slide cultures with potato dextrose agar after 1 week. Glucose is not fermented. The following carbon compounds are assimilated: D-glucose, D-galactose, D-xylose, Lsorbose (weak), D-glucosamine (weak), glycerol, 2-keto-Dgluconate (weak), DL-lactate, succinate, citrate (weak), ethanol, propane-1,2-diol and butane-2,3-diol. No growth on D-ribose, L-arabinose, D-arabinose, L-rhamnose, maltose, $\alpha, \alpha$-trehalose, cellobiose, salicin, arbutin, melibiose, sucrose, lactose, raffinose, melezitose, inulin, starch, erythritol, ribitol, xylitol, L-arabinitol, D-mannitol, glucitol, galactitol, myo-inositol, D-glucono-1,5-lactone, 5-keto-Dgluconate, D-gluconate, D-glucuronate or methanol. Ethylamine and cadaverine are assimilated, but not nitrate, nitrite or lysine. Growth in a vitamin-free medium is positive. Exhibits good growth at $28{ }^{\circ} \mathrm{C}$, weak and variable growth at $37{ }^{\circ} \mathrm{C}$ and no growth at $42{ }^{\circ} \mathrm{C}$. There is also no

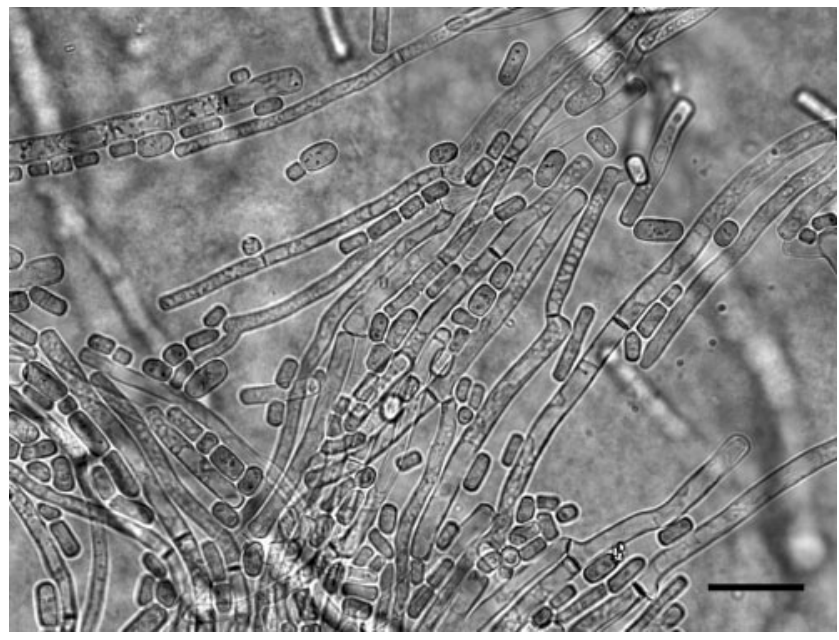

Fig. 2. Bright-field micrograph of growth of Geotrichum bryndzae sp. nov. CCY $16-2-1^{\top}$. True hyphae and arthroconidia are shown after 3 days of growth on yeast extract/malt extract agar at $25{ }^{\circ} \mathrm{C}$. Bar, $20 \mu \mathrm{m}$. growth in $50 \%$ glucose. Growth occurs at $0.01 \%$ cycloheximide, while growth at $0.1 \%$ is variable. Urease activity is negative; does not produce starch or extracellular amyloid compounds.

The type strain is CCY $16-2-1^{\mathrm{T}}\left(=\mathrm{NRRL}\right.$ Y $-48450^{\mathrm{T}}=\mathrm{CBS}$ $\left.11176^{\mathrm{T}}\right)$, which is deposited in the Culture Collection of Yeasts in the Institute of Chemistry, Slovak Academy of Sciences, Bratislava, Slovakia. The Mycobank accession number is MB 512675.

\section{Acknowledgements}

We thank E. Procházka for critical reading and R. Marshall for reviewing the English text. This project was funded by grants VEGA 1/ 3242/06, VEGA 1/0108/03 and Merck spol. s.r.o.

\section{References}

Altschul, S. F., Gish, W., Miller, W., Myers, E. W. \& Lipman, D. J. (1990). Basic local alignment search tool. J Mol Biol 215, 403-410.

Altschul, S. F., Madden, T. L., Schäffer, A. A., Zhang, J., Zhang, Z., Miller, W. \& Lipman, D. J. (1997). Gapped BLAST and PSI-BLAST: a new generation of protein database search programs. Nucleic Acids Res 25, 3389-3402.

Barnett, J. A., Payne, R. W. \& Yarrow, D. (2000). In Yeasts: Characteristics and Identification, 3rd edn, pp. 388-394. Cambridge: Cambridge University Press.

Boutrou, R. \& Guéguen, M. (2005). Interests in Geotrichum candidum for cheese technology. Int J Food Microbiol 102, 1-20.

Defontaine, A., Lecocq, F. M. \& Hallet, J. N. (1991). A rapid miniprep method for the preparation of yeast mitochondrial DNA. Nucleic Acids Res 19, 185.

de Hoog, G. S. \& Smith, M. T. (2004). Ribosomal gene phylogeny and species delimitation in Geotrichum and its teleomorphs. Stud Mycol 50, 489-515.

de Hoog, G. S., Smith, M. T. \& Guého, E. (1986). A revision of the genus Geotrichum and its teleomorphs. Stud Mycol 29, 1-131.

de Hoog, G. S., Smith, M. T. \& Guého, E. (1998a). Dipodascus de Lagerheim. In The Yeasts, a Taxonomic Study, 4th edn, pp. 181-193. Edited by C. P. Kurtzman \& J. W. Fell. Amsterdam: Elsevier.

de Hoog, G. S., Smith, M. T. \& Guého, E. (1998b). Galactomyces Readhead \& Malloch. In The Yeasts, a Taxonomic Study, 4th edn, pp. 209-213. Edited by C. P. Kurtzman \& J. W. Fell. Amsterdam: Elsevier.

Desmasures, N., Bazin, F. \& Guéguen, M. (1997). Microbiological composition of raw milk from selected farms in the Camembert region of Normandy. J Appl Microbiol 83, 53-58.

Fell, J. W., Boekhout, T., Fonseca, A., Scorzetti, G. \& StatzellTallman, A. (2000). Biodiversity and systematics of basidiomycetous yeasts as determined by large-subunit rDNA D1/D2 domain sequence analysis. Int J Syst Evol Microbiol 50, 1351-1371.

Felsenstein, J. (1988). Phylogenies from molecular sequences: inference and reliability. Annu Rev Genet 22, 521-565.

Kurtzman, C. P. (2006). Yeast species recognition from gene sequence analyses and other molecular methods. Mycoscience 47, 65-71.

Kurtzman, C. P. \& Fell, J. W. (editors) (1998). The Yeasts: a Taxonomic Study, 4th edn. Amsterdam: Elsevier.

Kurtzman, C. P. \& Robnett, C. J. (1998). Identification and phylogeny of ascomycetous yeasts from analysis of nuclear large subunit (26S) ribosomal DNA partial sequences. Antonie van Leeuwenhoek 73, 331-371. 
Lachance, M. A., Daniel, H. M., Meyer, W., Prasad, G. S., Gautam, S. P. \& Boundy-Mills, K. (2003). The D1/D2 domain of the large subunit rDNA of the yeast species Clavispora lusitaniae is unusually polymorphic. FEMS Yeast Res 4, 253-258.

Laurenčík, M., Sulo, P., Sláviková, E., Piecková, E., Seman, M. \& Ebringer, L. (2008). The diversity of eukaryotic microbiota in the traditional Slovak sheep cheese - Bryndza. Int J Food Microbiol 127, 176-179.

Marinoni, G., Manuel, M., Petersen, R. F., Hvidtfeldt, J., Sulo, P. \& Piškur, J. (1999). Horizontal transfer of genetic material among Saccharomyces yeasts. J Bacteriol 181, 6488-6496.

Naumova, E. S., Smith, M. Th., Boekhout, T., de Hoog, G. S. \& Naumov, G. I. (2001). Molecular differentiation of sibling species in the Galactomyces geotrichum complex. Antonie van Leeuwenhoek 80, 263273.

Pimenta, R. S., Alves, P. D. D., Corrêa, A., Jr, Lachance, M. A., Prasad, G. S., Rajaram, Sinha, B. R. \& Rosa, C. A. (2005). Geotrichum silvicola sp. nov., a novel asexual arthroconidial yeast species related to the genus Galactomyces. Int J Syst Evol Microbiol 55, 497-501.
Smith, M. Th. \& Poot, G. A. (2003). Genome comparisons in the genus Dipodascus de Lagerheim. FEMS Yeast Res 3, 301-311.

Smith, M. Th., Poot, G. A. \& de Cock, A. W. A. M. (2000). Reexamination of some species of the genus Geotrichum Link: Fr. Antonie van Leeuwenhoek 77, 71-81.

Thompson, J. D., Gibson, T. J., Plewniak, F., Jeanmougin, F. \& Higgins, D. G. (1997). The CLUSTAL_X windows interface: flexible strategies for multiple sequence alignment aided by quality analysis tools. Nucleic Acids Res 25, 4876-4882.

Ueda-Nishimura, K. \& Mikata, K. (2000). Two distinct $18 \mathrm{~S}$ rRNA secondary structures in Dipodascus (Hemiascomycetes). Microbiology 146, 1045-1051.

Wuczkowski, M., Bond, C. \& Prillinger, H. (2006). Geotrichum vulgare sp. nov., a novel asexual arthroconidial yeast. Int J Syst Evol Microbiol 56, 301-303.

Yarrow, D. (1998). Methods for the isolation, maintenance and identification of yeasts. In The Yeasts, a Taxonomic Study, 4th edn, pp. 77-100. Edited by C. P. Kurtzman \& J. W. Fell. Amsterdam: Elsevier. 